\title{
Associations of GCLM, gclc and GSTP1 gene polymorphisms and antituberculosis drugs- induced hepatitis
}

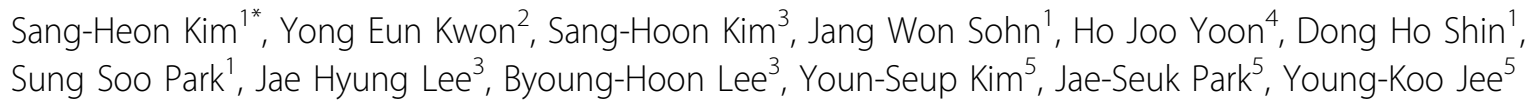

From 3rd WAO International Scientific Conference (WISC) 2014

Rio de Janeiro, Brazil. 6-9 December 2014

\section{Background}

Antituberculosis drugs (ATD) is the most common cause of drug-induce liver injury in many countries. While the mechanism of ATD-induced hepatitis is poorly understood, oxidative stress is suggested to be involved in the development of liver injury to drug metabolites. In this regards, we explored the possible associations between glutathione related enzymes (GCLM, GCLC and GSTP1) gene polymorphisms and ATD-induced hepatitis.

\section{Methods}

Through regular monitoring of liver function test during the treatment of tuberculosis, 84 patients with ATDinduced hepatitis and 237 ATD-tolerant controls were enrolled. Genotype were assessed in 3 single nucleotide polymorphisms in GCLM (rs41303970, $-590 \mathrm{~T}>\mathrm{C}$ ), GCLC ( $r s 17883901,-594 \mathrm{~T}>\mathrm{C})$ and GSTP1 (rs1695, I105V) and compared between case and control groups.

\section{Results}

No significant difference was found in genotype frequencies of rs41303970, rs17883901 and rs1695 between patients with ATD-induced hepatitis and ATD-tolerant controls in three statistical models (dominant, recessive and codominant model). In addition, the minor allele frequency were not different between case and control group in three polymorphism sites.

\section{Conclusions}

There was no significant association between GCLM, GCLC and GSTP1 gene polymorphisms and ATD-induced

'Hanyang University College of Medicine, South Korea

Full list of author information is available at the end of the article hepatitis. These findings suggest that genetic variants of GCLM, GCLC and GSTP1 do not increase the risk of ATD-induced hepatitis.

\section{Authors' details}

${ }^{1}$ Hanyang University College of Medicine, South Korea. ${ }^{2}$ Chosun University College of Medicine, South Korea. ${ }^{3}$ Eulji University School of Medicine, South Korea. ${ }^{4}$ Hanyang University Hospital, South Korea. ${ }^{5}$ Dankook University College of Medicine, South Korea.

Published: 8 April 2015

doi:10.1186/1939-4551-8-S1-A151

Cite this article as: Kim et al:: Associations of GCLM, gclc and GSTP1 gene polymorphisms and antituberculosis drugs-induced hepatitis. World Allergy Organization Journal 2015 8(Suppl 1):A151.
Submit your next manuscript to BioMed Central and take full advantage of:

- Convenient online submission

- Thorough peer review

- No space constraints or color figure charges

- Immediate publication on acceptance

- Inclusion in PubMed, CAS, Scopus and Google Scholar

- Research which is freely available for redistribution

Submit your manuscript at www.biomedcentral.com/submit
() Biomed Central 